European journal of American studies

Spring 2017: Special Issue - Eleanor Roosevelt and Diplomacy in the Public Interest

\title{
Eleanor Roosevelt's Radio Broadcasts in France
}

Anya Luscombe

\section{(2) OpenEdition}

Journals

Electronic version

URL: https://journals.openedition.org/ejas/11946

DOI: 10.4000/ejas. 11946

ISSN: 1991-9336

Publisher

European Association for American Studies

\section{Electronic reference}

Anya Luscombe, "Eleanor Roosevelt's Radio Broadcasts in France", European journal of American studies [Online], 12-1 | 2017, document 8, Online since 14 March 2017, connection on 08 July 2021. URL: http://journals.openedition.org/ejas/11946 ; DOI: https://doi.org/10.4000/ejas.11946

This text was automatically generated on 8 July 2021 .

Creative Commons License 


\title{
Eleanor Roosevelt's Radio Broadcasts in France
}

\author{
Anya Luscombe
}

1 In January 1952 one Frenchman was prompted by Eleanor Roosevelt's broadcasts on the French National Network and Voice of America to send the former First Lady a poem:
2 When the radio broadcasts your voice,
3 The whole country hastens to hear your words.
4 Because you have the gift to dispel doubt
5 That sometimes haunts our soul.
$6 \quad(\text { Hommage, 1952) })^{\mathrm{i}}$

While a poem was perhaps an unusual way to express admiration, this was by no means the only correspondence praising Mrs. Roosevelt and the work she was doing as part of the US delegation to the United Nations meeting in Paris. By the same token though, there were plenty of letters expressing criticism, even disgust. Mrs. Roosevelt was no stranger to receiving comments from listeners. Ever since she started her broadcast career in the 1920s, she had received, indeed courted, commentary. It was one way for her to see that her communicative strategies were having success and to obtain additional feedback. Mrs. Roosevelt first took to radio on behalf of the women's City Club of New York in $1925^{\mathrm{ii}}$ and in the 1930s and 1940s she had several lucrative radio series. Radio gave her an income, which afforded her some independence as a woman and the ability to comment on important matters ${ }^{\text {iii }}$, as well as the opportunity to donate to charities such as the American Friends Services Committee. However, it was also one part of the media mix she deftly used in her roles of human rights campaigner, political activist and educator, alongside her newspaper columns, speeches, books and articles for magazines (such as McCall's and Ladies Home Journal). The mass medium of radio allowed her to reach a broader audience in the US and notably also, which is the point of this essay, foreign listeners in their homes abroad. Media is an essential part of public diplomacy, described by Nye as an instrument used by governments to "attract 
the publics of other countries [...] through broadcasting, subsidizing cultural exports, arranging exchanges and so forth." iv Particularly in the Cold War, radio was "one of the weapons of choice."v

8 Mrs. Roosevelt was astute enough to realize the enormous impact radio communication direct into ordinary people's homes could have and she capitalized on the medium's ability as 'soft power' to reach the hearts and minds of Europeans to convince them of the American point of view by regularly appearing on VOA broadcasts. From November 1951 to February 1952, she hosted a series of VOA weekly radio commentaries for the French National Network, RDF, which were aimed at explaining to families in France and other French-speaking countries the workings of the UN and to urge Europeans to work together for peace. This paper adopts a case study approach and aims, by a close reading of these radio commentaries and US State Department documents, ${ }^{\text {vi }}$ to assess the impact of ER's messages, which were aimed at promoting transnational peace and human rights. In addition, the paper attempts to assess how American cultural diplomacy benefitted from Eleanor Roosevelt's broadcasts. While there is a substantive body of literature on Cold War broadcasting, much of it focuses on broadcasting from the West, particularly the USA and Britain, to the countries behind the Iron Curtain. ${ }^{\text {vii }}$ This essay aims to add a new perspective by examining radio in France. First, however, the next chapter will consider the role of US broadcasting to Europe and Mrs. Roosevelt's views on its relevance.

\section{US International broadcasting and the early Cold War}

US international broadcasting in the early part of the Cold War (1946-53) was focused on the policy of containment. viii The Voice of America had started operations in February 1942 as part of the US policy to combat German propaganda and by 1944, the VOA was broadcasting in more than forty languages. ${ }^{i x}$ After World War II, the State Department and politicians were less willing to continue to fund programming. ${ }^{\mathrm{x}}$ Mrs. Roosevelt argued that now was not the time to give up on international broadcasting; writing in her My Day Column of May 9, $1947^{\text {xi }}$, she criticized Congressional representatives who only believed in appropriating funding for military projects:

10 It is a curious thing that just at this time Congress should want to silence the State Department's radio program, the Voice of America...

11 One grows to feel that our representatives in Congress are willing to give money for military opposition to Communism, but are not willing to give money to the spread of intellectual understanding of democracy. Yet if we do not want to see our sons go off to war again, we must spread the understanding of the value of our way of life and of our type of government...

12 [I]f we stop talking to the rest of the world, we cannot even tell them what our achievements have been, nor can we explain the reasons for the positions we take.

Mrs. Roosevelt also used her domestic radio programs to emphasize how international radio could act as a social force for good. In the January 26, 1949 edition of theEleanor \& 
Anna Roosevelt Program, Mrs. Roosevelt told her listeners on the ABC network about a VOA program she had just completed in remembrance of her late husband.

14 [These Voice of America broadcasts are] really the way in which we [...] as the United States government try to get across life of the United States, the thinking of its people, the facts about our country to the peoples in the rest of the Europe. It's perhaps our best way of getting beyond the Iron Curtain...we don't really know how much we get beyond, but we hope a good deal gets beyond. .ii $^{\text {m }}$

She went on to dismiss fears voiced by several representatives in Congress and the American people about paying for propaganda. American listeners ought to think of Voice of America broadcasts as advertising, she argued. If it was perfectly natural for American consumers to accept commercial advertising, then they should also approve of propaganda which in her mind was a much needed chance to tell the truth:

16 Some of the ideas that people have about us in other parts of the worlds are strange indeed and the more we can change those ideas and the more we can get across the truth, the better it will be for the real things that have to be done in diplomacy and in our economics with other countries, practically even in military questions it's necessary that other countries get to know us better. xiii(Her emphasis)

Mrs. Roosevelt appeared to believe therefore, that US, i.e. advertising-like, propaganda was distinct from the Soviet propaganda which consisted of falsehoods and fear mongering. xiv

18 As the perceived threat from the Soviet Union mounted, evidenced by developments such as the Berlin Blockade and the coup in Czechoslovakia in early $1948^{\mathrm{xv}}$ as well as heavy Soviet investments in their own international broadcasting, political support slowly started to swing behind increased funding for the Voice of America. While the American public might be suspicious about propaganda, the US State Department saw it as a necessary alternative to an over-reliance on military strength in Europe. As Cull says, government officials worried that "military power dissociated from a persuasive idea may neither deter an enemy nor persuade an ally." ${ }_{x v i}$ Several government officials and reports argued for increased budgets for international broadcasting, stressing its importance both as a means to get beyond the Iron Curtain and to raise the morale of listeners in Western Europe who were trying to rebuild their lives in the aftermath of the Second World War. By 1950 President Truman called for 'a campaign of truth' to enable America to be heard round the world. $^{\text {xvii }}$ The US Under-Secretary of State, James Webb, proposed $\$ 130$ million to be spent on new operators and transmitters. ${ }^{\text {xviii }}$ Research by Nelson in the archives of the central committee of the communist party of the Soviet Union "confirmed that Communists believed that Western radio propaganda was the strongest and most effective weapon that existed for ideological intervention in the Soviet Union." ${ }^{\text {xix }}$ In October 1950, on The Eleanor Roosevelt Program, Mrs. Roosevelt interviewed BrigadierGeneral David Sarnoff, President of RCA, who had testified before a Senate Committee about the importance of the Voice of America. As the following part of the exchange shows, Eleanor Roosevelt remained concerned that still not enough funding was going to the VOA: 
19 Sarnoff: [W]e must do more than merely tell the story of America itself. We must tell the big truth about the big lie. What we need to do is to have counter propaganda first, that is, to dissect the lives that the communists are telling wherever they have facilities to tell them. If truth is incapable of overtaking untruth, then there's something seriously wrong with our whole structure of life but I am confident that the truth will prevail. It must prevail [...]

20 Roosevelt: In your testimony General [...] [y]ou said that no matter how good our message may be, nobody can listen to it unless we furnish the facilities with which to transmit it. My question is, do you think our facilities are extensive enough and strong enough to be heard throughout the world?

21 Sarnoff: No, Mrs. Roosevelt, I do not think that the facilities of the Voice of America are sufficient, but I am glad that Congress recently acted favorably on the President's recommendation to appropriate 57 million dollars for the Voice of America. As a result I am hopeful that the State department can now do a more comprehensive job.

22 Roosevelt: There's a difference between 57 million and 200 million though that still has to be covered and that is something that we must consider I suppose. ${ }^{\mathrm{xx}}$

23 The importance the US attached to broadcasting as a Cold War strategy was further emphasized by the setting up of Radio Free Europe in 1950 and Radio Liberty in 1953. ${ }^{x i}$ Mainly funded by US Congress through the Central Intelligence Agency, RFE also received donations from private individuals. In herMy Day column of September 1, 1951, Mrs. Roosevelt urged the US public to contribute to the Crusade for Freedom which sponsored RFE:

24 ...Radio Free Europe [...] has just opened a station powerful enough to reach over into the satellite countries. The opening date of the campaign is September 3 and the Crusade for Freedom will be appealing to all of us in this country for funds. Plans are in the making to expand their radio work and really bombard the Iron Curtain countries with as much truthful information as they can get across. ${ }^{\text {xxii }}$

It seems natural that radio should have played a key role in communicating America's viewpoints at the time. While the number of radio receivers in European countries was significantly lower than in the USA, (e.g. 176 receivers per 1000 inhabitants in France in 1951, 207 in the Federal Republic of Germany and just 70 per 1000 inhabitants in the USSR - compared to an estimated 620 radio receivers per 1000 inhabitants in the US ${ }^{\text {xxiii }}$ it was nevertheless estimated that the vast majority of the population at the time did have access to news, information and entertainment through the wireless. For example, in the US zone in Germany, the VOA believed regular audiences were over six million $^{\text {xxiv }}$ and the USIS Radio Unit in France wrote to the State Department in 1952 that approximately 20 million persons were considered radio listeners. ${ }^{\mathrm{xxv}}$ 


\section{The USA and France}

26 In the early 1950s European countries were still struggling to rebuild themselves from the ravages of war and trying to establish a "durable balance of power in Europe". ${ }^{x x i}$ The sense of vulnerability felt by the citizens of Europe in the post-war period was aptly described by the Hungarian author and journalist, Arthur Koestler, in 1951:

27 Life in Europe has become a picnic in no man's land...The reality of living in the no man's land between the fronts, virtually defenceless against the threat of annihilation which may materialize next year or next month, is too hideous to be faced. And when reality cannot be faced the obvious solution is to escape into a neurotic dream world. From time to time Europe gets into a panic and then reality breaks through for a short moment of truth, like a flicker on the screen. But the psychic operator quickly readjusts the machine, and the shadowy delusion continues [...] "The inescapable conclusion is bitter to admit for us Europeans and unpleasant to accept for you Americans. We know that you haven't asked for this tragic responsibility and that you are not prepared for it. But history casts its parts without regard for the actors' wishes. ${ }^{\text {xxvii }}$

The vulnerability was palpable throughout Europe, not only in those countries in the Eastern part of the continent. The USA recognized that the Soviet sphere of influence had the potential to reach much further than the Communist side of the curtain; in particular it feared that France and Italy, where the Communist parties enjoyed a great deal of popular support, might be swayed towards the Soviet style of government over US style democracy. France had been devastated by the war; one fifth of all housing and much of the country's infrastructure had been damaged or destroyed. ${ }^{x x v i i}$ Additionally, food shortages meant rationing was needed, which led to concerns about public health. ${ }^{\text {xxix }}$ The Marshall Plan implemented in 1948 was seen as one of the remedies: if people had better standards of living, it was reasoned, they might not be as easily tempted by the Soviets. ${ }^{x x x}$ However, as Alessandro Brogi argues, the US had to employ a far larger toolkit than merely economic diplomacy in France as there the Marshall Plan was "less understood and less appreciated" than in the rest of Western Europe. ${ }^{\mathrm{xxi}}$ The Soviet Union's efforts to cast itself as the only true advocate of peace and the US as "soulless warmongering capitalism"xxxii was well-received in many European circles, not only among Communists, but also intellectuals and conservative groups wary of Americanism; France had all of these three groups. ${ }^{\text {xxxii }}$ The USA's need to get the French to agree to its post-war security plans meant it refrained from openly opposing French colonialism. On the contrary: between 1950 and 1954 America contributed \$3 billion to France's military campaign in Indochina. ${ }^{\text {xxiv }}$ Moreover, the US government poured vast sums of money into cultural diplomacy, including broadcasting, concerts, exhibitions and libraries. ${ }^{\mathrm{xxx}}$ In May 1950, Under-Secretary of State, James Webb, called for militarily, economically and strategically vulnerable France to be one of the nations that should be targeted by the VOA as a matter of priority. ${ }^{\text {xxxvi }}$ The VOA produced its 
own programs like Ici New York which was relayed over French stations and supplied materials and expertise to both RDF and France Inter. ${ }^{\text {xxvii }}$ The difficult situation facing the VOA in France at the time - and by extension US public diplomacy programs - is evident from reports sent from Paris to the State Department. They show a picture of frequently recommending increased funding and a better targeting of French audiences. For example, a Telegraph sent to the Secretary of State in July 1951 describes how the VOA program Ici New York had chosen to include more news of the Korean conflict because of a "need on the part of the French public to have more news. Today VOA is obliged to modify its perspectives which are chiefly psychological and therefore very complex. VOA must not (rpt not) only find radio listeners but retain them." xxxvii The missive goes on to criticize the approach taken by a number of recent features:

29 June 8 Feature. 22 minutes on American economic situation. "Well done for Americans, not good for Frenchmen."

30 June 22 Feature. Interview with Walter White ${ }^{\mathrm{xxxix}}$. "Well done, but not convincing. White not known in France."

31 June 26 program. Raymond Swing's political "commentary does not carry sufficient weight [...] he seemed to forget completely that France was also engaged in the Far East."

The June 1950 report from USIS radio section in Paris mentions that 15,000 copies of the French language schedules for July-August would be distributed throughout France, as well as 1500 language schedules. ${ }^{x l}$ The photograph on the cover of those schedules is that of Mrs. Eleanor Roosevelt and her late husband's dog, Fala.

\section{Eleanor Roosevelt commentaries 1951-52}

In the fall of 1951, Eleanor Roosevelt was in Paris with the US delegation to the sixth session of the United Nations General Assembly. Earlier that year, Mrs. Roosevelt, who had been a member of the US delegation to the UN since 1946, had handed over the chairmanship of the Human Rights Commission to Dr. Charles Malik from Lebanon. Under Mrs. Roosevelt's able chairmanship, the Commission had drafted the Universal Declaration of Human Rights which was approved by the General Assembly in 1948. . $^{\text {li }}$ The head of the VOA's French service, Fernande Auberjonois, asked her to broadcast weekly commentaries about her work as he felt she was the "only logical choice [...of person who could] establish a link with the French public." "xli According to New York Times correspondent, Richard Gardner, Auberjonois thought "Mrs. Roosevelt had assets possessed in Europe by no one else - a beloved and respected name, a reputation in her own right as a diplomat and a fighter for social justice, and a simple feminine manner which would appeal to the average listener." "liii What precisely is meant by a 'simple feminine manner' is not clear; possibly the "warm, persuasive voice" and the "kind, restful words" "xliv mentioned by listeners quoted in the article are the characteristics Gardner and American readers in the early 1950s would think as constituting fitting behavior and tone for a woman.

34 The commentaries which ran from 18 November 1951 to 3 February 1952 were broadcast over the French National Network on Sunday evenings at 8 p.m. Paris time and could also be heard in Belgium, Switzerland, Eastern Europe and North Africa 
through the facilities of the Voice of America. ${ }^{x / v}$ Although Mrs. Roosevelt singled out women in her audience for the first commentary by saying: "I think that what you want to know - especially you the women of post-war Europe..." "xlvi, it is most likely that both genders would have been listening to the radio at that time of day at the weekend. ${ }^{\text {xlvi }}$ In each approximately 1000-word commentary delivered in French, Mrs. Roosevelt aimed to explain the work of the US delegation at the Palais de Chaillot that week. She mixed personal stories about places she had visited and people she had met with information about the UN and the issues of peace and nuclear disarmament. As an accomplished broadcaster, she used a number of stylistic features to effectively communicate with her listeners, which will be highlighted in examples from three broadcasts.

\section{Sunday November 18, 1951}

In this first commentary, Mrs. Roosevelt's style is a simple one, with mainly short sentences. She frequently uses the inclusive first person 'we' to denote to her audience that they share a common cause, i.e. to "work at building peace". The most vivid and effective style figure in this particular talk is the metaphor comparing peace to a vulnerable plant, which Eleanor Roosevelt employs to make clear the abstract concept of peace:

36 I believe that peace is something you must cultivate with great care and tenderness.Like certain delicate plants and flowers peace needs warmth and love. Cynicism and abuse will harm it. However, if those who wish it well do something to protect peace, it can and it will grow. .lviii $^{\text {. }}$

The verbs that accompany the metaphor "cultivate, protect, grow" not only form a climax in themselves, but also add to the metaphor's persuasive power by suggesting that peace will have a chance to blossom if all nations of the world work together on tending the jointly owned garden that is the globe. She extends the metaphor by going on to contrast delicate plants with weeds and by alluding to her own experiences of gardening appears to imply that she - just as other Americans who desire peace knows what she is talking about:

38 Like most Americans, I have a garden. I know that nothing can really grow if the soil has not been cultivated, ploughed, and fertilized. Nothing grows in a poor soil. After the war, Europe's soil was poor. We know then that a lasting peace could not grow from the acrid soil of human misery, among the shambles of war, in the cold shade of despair.

By using inclusive language and metaphors to explain abstract concepts like peace, Mrs. Roosevelt hoped to to achieve a favorable reaction from the audience to her, the US delegation and the message.

\section{December 16, 1951}

Mrs. Roosevelt uses the stylistic device of anticipation in this commentary to talk about the daily correspondence received by all UN delegates as a way to refute the Soviet argument that America does not desire peace: 
41 Certain correspondents send me criticism because, according to them, sometimes I judge severely my colleagues from the delegations from countries of the East. They say to me: “Why don't you carry out the policy of the extended hand?" To this I will reply: "Yes, but it is necessary that two hands be stretched out at the same time." I have very often made this gesture. I found myself before people who do not dare to answer. I don't think that they are afraid of us. They are afraid of themselves.

43 At times I should like to exchange a few words with a delegate whose views I do not share and who does not agree with me. But as soon as the conversation has begun, the other members of the delegation rush up and form a block.

She then chooses to focus on one particular letter she received which had been signed by 21 different people from La Plaine Montferrand. By stressing that these ordinary French people speak for themselves and do not engage in propaganda, she contrasts their genuineness and right of self-expression and critical thinking with the dishonesty and group-think of the Soviet delegates.

45 They honestly say what they have on their minds, without making any propaganda. They speak for themselves, not for a party or a foreign power. They speak without bitterness and I understand them well when they say: "We are terribly worried. We have known two wars and though our suffering is not yet alleviated nor our ruins rebuilt, there is already talk of a Third World War which would end in the destruction of humanity. You are the Organization of the United Nations on which we rely to maintain peace."

Her reply to these writers is that "peace demands of us great effort and great sacrifices" [...] Will we in the United Nations be worthy of your trust? I certainly hope so. We must be." She then turns to the radio listeners as a whole with a direct message to those who might share the letter writers' concerns: "hold firm to your will for peace; and make sure that peace is safeguarded by deeds and not merely by words."

47 The French communist newspaper, L'Humanité, which had been critical of Mrs. Roosevelt's previous commentaries, was particularly enraged by the December 16 broadcast. It accused France of being partial to the US by not offering other delegations the opportunity of taking to the airwaves.

48 [A]n excellent initiative on the part of France, [...] to place the radio at the disposal of members of the principal delegations; an initiative which honors the radio, don't you think? Yes. But the American delegation is the only one to benefit from it, and you can keep on waiting for the objectivity of Radio Paris to offer you a weekly broadcast by Malik or Vychinski. ${ }^{x i x}$

The editorial twice uses the phrase "embarrassed" to describe Mrs. Roosevelt's attitude during what it calls her "obliged" reply to the people who have written to ask about 
peace. The tone of indignation is palpable when it accuses Mrs. Roosevelt of insincerity and piety:

50 Mrs. Roosevelt continues by insinuating that those who write to ask for an understanding with the East are speaking "for a party" or "for a foreign power" (as if she has a right to complain about that!) [...]As a matter of fact, there is not one word in all her sermon about the five-power pact.

\section{February 3, 1952} not just a farewell to her French listeners, but used by Mrs. Roosevelt as an opportunity to defend her decision to "talk to you in your homes...on your network" and to launch a vociferous attack on the Soviet delegate Andrey Vishinsky. She shows a sense of American exceptionalism when she talks about the role that has been thrust upon the USA:

52 In the field [of nuclear disarmament] we are doubtless more perfectionist than the Soviets [...] My country has been selected by destiny to carry at this time a heavy burden of responsibility. I am aware that new and thankless tasks will be ours to perform. We must accept them with pride. It is our duty to inspire confidence and assist the peoples of the world to recovery [...] I believe that today, more than ever, that to quote "you have nothing to fear but fear itself."

Eleanor Roosevelt fully understood what doing one's duty meant as she herself had been the prime example of someone who had done exactly that throughout her career. Now it was her duty on behalf of the US to inspire the world and to carry on the legacy of her husband Franklin whom she quoted in the commentary's final sentence. She for one, was ready - as Koestler had urged - to play the part that history had cast upon the United States.

\section{Reactions to VOA commentaries}

The USIS Radio Unit put the listening figures for Mrs. Roosevelt's French commentaries at approximately five million', significantly less than the "at least 15 million" which The New York Times' Richard Gardner mentioned in his 1952 article. ${ }^{\text {li }}$ Whereas USIS figures presumably referred to those listening on French National Radio and Gardner's reported estimate also included publics reached by the VOA relays (to Belgium, Switzerland, Eastern Europe and North Africa), it is impossible to verify the additional 10 million. As Risso cautions, statistics, surveys and anecdotes provided by national agencies and broadcasters cannot always be trusted, and scholars can only make an educated guess about a broadcast's efficacy. ${ }^{\text {lii }}$ According to Nye, government-funded radio broadcasts (US and British) "reached half the Soviet population every week and between 70 and 80 percent of the populace of Eastern Europe during the Cold War." "liii UNESCO figures, however, show a much more conservative picture ${ }^{\text {liv }}$, and a reach of more than $70 \%$ does on the face of it appear somewhat over-optimistic. USIS acknowledged the difficulties inherent in determining actual sizes of audiences, let 
alone the impact of particular broadcasts. In the case of France where people could speak freely and data gathering would have been easier than behind the Iron Curtain, an estimate of five million for Mrs. Roosevelt's broadcasts does seem feasible. Her broadcasts appeared to have much higher ratings than many other VOA programs broadcast over the French National Network. For example, Ici New York on weekdays attracted 1-1.5 million listeners, its Sunday edition an estimated 2-3 million, and weekly programs of American music appealed to more than 3 million. The USIS report of 1952 argued that the critical articles in the Communist Press, such as the L' Humanite editorial in section 3.2 above were "one of the best proofs of effectiveness of [Mrs. Roosevelt's] talks [...]. These Communist attacks used Mrs. Roosevelt as a pretext for attacking the VOICE OF AMERICA." ${ }^{\text {"lv }}$

55 Letters from listeners available in the archives also offer an interesting, if only partial, insight into America's cultural diplomacy efforts. VOA offices received large amounts of correspondence every month. According to the Guild Reporter, 98,630 letters were sent from a variety of countries to the VOA in the period October 1948 to May 1949, of which just two percent was unfavorable. ${ }^{\text {lvi }}$ A December 1951 survey by the VOA speaks of several hundred letters that have been received by the Radio Diffusion offices in response to Eleanor Roosevelt's commentaries. A second survey of reactions to the broadcasts, dated January 5, 1952 reports an increase in volume of mail: "approximately two thirds of the letters emanate from listeners with a relative modest cultural background and whose standard of living appears to be low" "vii. Many correspondents expressed admiration:

56 "Every time I listen to you I feel more deeply moved by your sincerity and your ardent desire to convince your listeners. No Frenchman can listen to you without expressing his deep gratitude. (Mr. F.L. retired)",

others accused her of deceit: "You know full well, Madame, that the USSR does not intend to attack us... (A group of listeners...Rhone)"

58 or cast aspersions on what the writer considered ER's lack of appropriate female behavior:

59 Although I am getting used to the cynical lies of the Voice of America I never would have believed that a woman, even an American woman, would dare side with the American warmongers...You dare speak of the Rights of Man while you emprison Communists and lynch negroes. (P.B. Sete, Harault)

The official view of USIS was that the commentaries were a resounding success, thanks entirely to the ER's ability to speak plainly, as voiced by USIE Regional Representative Charles Hulten in a letter to Edward W. Barratt, the Assistant Secretary of State for Public Affairs:

61 I have yet to meet a person in Europe who doesn't feel that the big problem the United States faces is to convince the people of Europe that our common adventure will not lead to fear [...] One of the blessings of having had Mrs. Roosevelt in Paris for the last several months is that she has cut through the "footnote psychology" which besets people who 
write guidances and has said, simply and straightforwardly, that the United States wants peace. In doing that, she has not only had a terrific affirmative effect, but she has also provoked the communists and their fellow-travellers to exceptional counter-activity. ${ }_{\text {!vii }}$

The VOA went on to ask Mrs. Roosevelt to record messages in Italian, Spanish and German to reach audiences in many of the other countries to which it broadcast. lix

\section{Conclusion}

Broadcasting, in particular the Voice of America, was a key weapon in the US' battle for the hearts and minds of the citizens of Europe, both East and West, during the early years of the Cold War. In France, the State Department acknowledged the importance of broadcasting and other forms of public diplomacy as a complement to economic and political strategies and to counter anti-American sentiment. Kelly posits that anecdotes are insufficient to measure the success of public diplomacy during the Cold War and that facts and judgments are more objective measures"lx ; Risso too argues that historians "cannot measure the actual impact of information programs on the public, [but] they can [...] measure the perceived success of such programs in the eyes of their promoters and [...] what their personnel thought were the interests, sensibilities, and concerns of their listeners." "xi Primary research in the State Department files does then seem to confirm the importance and success of Eleanor Roosevelt's radio contributions as does the fact that the Communist Press in France chose to complain about them. During her tenure at the United Nations, Eleanor Roosevelt was an official US diplomat, one of a select number of women to perform such an important role. As a stateswoman she was highly influential: "Without her leadership, the Declaration [of Human Rights] would not have been adopted and the Covenants on both civil and political rights as well as social and economic rights would not have been initiated." "xii

64 Her official role did not mean she always concurred with President Truman's or the State Department's views, for example on social and economic rights where she felt America should do much more, or in her critique of the Truman Doctrine and the

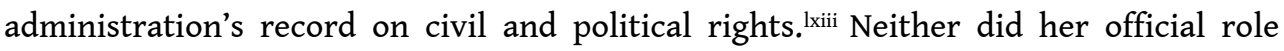
mean Mrs. Roosevelt was always fully informed by the government. Her assertion that the Crusade for Freedom which sponsored Radio Free Europe was "carried on not by the government, but by private funds and individuals" "xiv was evidently mistaken. In reality the CIA was heavily involved in the financing of Radio Free Europe and Mrs. Roosevelt's plea to American citizens to contribute to the Crusade raises the question as to whether she was lying or being naïve. As someone who argued forcefully for telling the 'truth' at all times, perhaps she expediently chose not to probe further or possibly the Truman administration chose not to tell her about CIA involvement in order to exploit her role as a public diplomat at home and abroad.

65 Besides her official diplomatic position as a member of the US delegation to the UN and as chair of the Human Rights Commission, she deftly played the role of cultural diplomat and expertly used the media to aid her performance. Radio, in particular, was one of the tools she chose to promote the UN and by extension the superiority of American perspectives on transatlantic relations. To her, the medium was essential in helping to reach the ordinary men and women who were part of her imagined 
community of free global citizens, together striving for peace and universal human rights. As she said,

66 "It is high time [...] that we not only have a stronger Voice of America but a very much better Voice of America, for we must declare our desire for peace. We must show that our efforts constantly made within our own nation, to bring about better understanding among people, are creating a greater devotion to the cause of peace in the world." "xv

Soft power was in her eyes a legitimate and necessary form of truthful propaganda, distinct from the lies and obstructions that formed the propaganda of the Communists. Her radio performances enabled ER to be a Cold War warrior and gave the US direct entry into the homes of those transatlantic audiences it wanted to ensure were on its side in the struggle for peace.

\section{NOTES}

i. The Papers of Eleanor Roosevelt 1945-1962 Part I: United Nations Correspondence and Publications. Reel 10. 184. Middelburg: Roosevelt Study Center Collection. This first stanza of the poem was translated by me and is a more literal translation than part of the poem which is referred to in a VOA memorandum (see note 58). In French the first stanza of the poem ran as follows: "Lorsque la radio diffuse votre voix, Le pays tout entier se met vite à l'écoute, Car vous avez de don de dissiper le doute Qui s'en vient obséder notre âme quelquefois."

ii. Blanche Wiesen-Cook Eleanor Roosevelt. Vol 1: 1884-1933(New York: Penguin, 1992). I am grateful to Maurine Beasley for her comments to me on this issue also.

iii. Paul Belgrade, "Radio Broadcasts" in The Eleanor Roosevelt Encyclopedia, Maurine H. Beasley, Holly C. Shulman \& Henry R. Beasley , eds., (Westport: Greenwood Press, 2001) 425-429.

iv. Joseph S. Nye Jr., "Public Diplomacy and Soft Power", in International Communication. A Reader, ed.Daya K. Thussu (London, New York: Routledge, 2008), 334.

v. Linda Risso, "Radio Wars: Broadcasting in the Cold War", Cold War History (2013, Vol 13, No.2): 145-152, doi: 10.1080/14682745.2012.757134.

vi. For all radio commentaries, the texts are available in English as "Press Releases" from the US delegation to the UN Written transcripts in French are available for some of the commentaries. These documents are available on microfilm in the Roosevelt Study Center in Middelburg, the Netherlands. Unfortunately, there are no audio recordings. The part transcription of the 1949 $A B C$ and 1950 NBC radio programs quoted from later in this essay were typed up by the author from the audio recordings available at the FDR library in Hyde Park NY and the RSC in Middelburg, respectively. The US state department documents were consulted at the National Archives at College Park, MD.

vii. For extended histories of the VOA, see for example Nicholas Cull, The Cold War and the United States Information Agency. American Propaganda and Public Diplomacy, 1945-1989 (New York: Cambridge University Press, 2008). Robert William Pirsein, The Voice of America. An history of the International Broadcasting Activities of the United States Government 1940-1962 (New York: Arno Press, 1979). Gary D. Rawnsley, Radio Diplomacy and Propaganda. The BBC and VOA in International Politics, 
1956-64. (London: Macmillan, 1996). Holly C. Shulman, The Voice of America: Propaganda and Democracy, 1941-1945 (Madison: University of Wisconsin Press, 1992). On the BBC specifically, Alban Webb recently published a detailed account of its Cold War Operations: London Calling. Britain, the BBC World Service and the Cold War (London, New York: Bloomsbury Academic, 2014) Also worth reading is Michael Nelson, War of the Black Heavens. The Battles of Western broadcasting in the Cold War (New York: Syracuse University Press, 1997) and Alexander Badenoch, Andreas Fickers andChristian Henrich-Franke, eds., Airy Curtains in the European Ether: Broadcasting and the Cold War (Institute for European Regional Research, Nomos, 2013).

viii. Gary D. Rawnsley, Radio Diplomacy and Propaganda. The BBC and VOA in International Politics, 1956-64. (London: Macmillan, 1996). For a detailed consideration of US containment policies during the Cold War, see for example John Lewis Gaddis, Strategies of Containment (Oxford: Oxford University Press, 2005).

ix. See note 8. Further information is also available on the VOA's history timeline on www.insidevoa.com.

x. Cull, The Cold War, 20.

xi. My Day. 9 May 1947, The Eleanor Roosevelt Papers project. George Washington University. https://www.gwu.edu/ erpapers/myday/displaydoc.cfm?_y=1947\&_f=md000647.

xii. Eleanor Roosevelt, Jan 26, 1949 Eleanor \& Anna Roosevelt Program. ER recorded speeches and utterances. 80-5 (22). FDR Library, Hyde Park.

xiii. Ibid.

xiv. Propaganda that is like advertising is sometimes referred to as white propaganda. See Garth Jowett and Victoria O'Donnell, Propaganda and Persuasion (Thousand Oaks: Sage, 2012).

xv. See for example Michael Creswell, “'With a Little Help from our Friends': How France Secured an Anglo-American Continental Commitment, 1945-54", Cold War History, 3:1 (2002): 1-28, doi: 10.1080 .713999975 .

xvi. Cull, The Cold War, 65.

xvii. Cull, The Cold War, 53.

xviii. Michael Nelson, War of the Black Heavens. The Battles of Western broadcasting in the Cold War (New York: Syracuse University Press, 1997), 55.

xix. Ibid., xiv.

XX. Interview Eleanor Roosevelt with David Sarnoff (1951). Eleanor Roosevelt Program (1950-1951). New York: NBC.[Radio Series], Roosevelt Study Center Collection, Middelburg, the Netherlands.

xxi. RFE's first broadcasts were to Bulgaria, Czechoslovakia, Hungary, Poland and Romania. Radio Liberty broadcast to the Soviet Union in 16 languages. See http://www.rferl.org/info/ history/133.html.

xxii. My Day. The Eleanor Roosevelt Papers project. George Washington University. https:// www.gwu.edu/ erpapers/myday/displaydoc.cfm?_y=1951\&_f=md002002.

xxiii. Statistics on radio and television 1950-60. UNESCO statistical reports and studies (Paris:UNESCO, 1963).

xxiv. Talk by Foy D. Kohler to Institute for education by radio-television Columbus Ohio, May 4, 1951. Container 13: Speeches 1951, P315 VOA Historical Files, NARA, College Park, Maryland.

xxv. Summary of USIS Radio Unit Activities, Dec 1, 1951 through May 31, 1952, D-107 p 44-52, Box 2385, RG59 511.51, NARA, College Park, Maryland. Even by 1961 less than 20 percent of households in France had a television set whereas 80 percent owned a radio. See Raymond Kuhn, The Media in France (London, New York: Routledge, 1995), 78

xxvi. Michael Creswell. "'With a Little Help from our Friends': How France Secured an AngloAmerican Continental Commitment, 1945-54.”, Cold War History, 3:1 (October 2002): 1. The worry of a possible Soviet invasion had prompted Britain, France, the Netherlands, Belgium and 
Luxemburg to form a military alliance, the Western Union, which ultimately led to the creation of NATO. Gaddis, Strategies of Containment, 70.

xxvii. Arthur Koestler, "The war of ideas", America and the Mind of Europe (London: Hamish Hamilton, 1951), 47-60.

xxviii. Rebecca J. Pulju, Women and Mass Consumer Society in Postwar France (Cambridge, New York: Cambridge University Press, 2011), 101. Gabriella Gribaudi, Olivier Wieviorka, Julie le Gac. "Two paths to the same End? The Challenges of the Liberation in France and Italy", in Seeking Peace in the Wake of War. Europe 1943-47, eds. Stefan Ludwig Hoffmann et.al, (Amsterdam: Amsterdam University Press, 2015), 91-116.

xxix. Gribaudi,Wieviorka, Le Gac, "Two paths”, 95.

xxx. William Hitchcock explains that Marshall also thought the only way to persuade France and others of the need to mobilize Germany was to create institutions that would regulate European recovery. Under the plan a total of $\$ 12.3$ billion was spent on aid to the whole of Europe. William I. Hitchcock, "The Marshall Plan and the creation of the West", The Cambridge History of the Cold War, eds. Melvyn P. Leffler, Odd Arne Westad (Cambridge: Cambridge University Press, 2010) 154-174, doi:10.1017/CHOL9780521837194), 154 and 157. France received more money from the US than any other country. See Irving M. Wall, the United States and the Making of Postwar France, 1945-54 (Cambridge: Cambridge University Press, 1991), http://assets.cambridge.org/ 97805214/02170/sample/9780521402170ws.pdf, 2.

xxxi. Alessandro Brogi, Confronting America. The Cold War between the United States and the Communists in France and Italy (Chapel Hill: University of North Carolina Press, 2011), 111.

xxxii. Giles Scott-Smith, Western Anti-Communism and the Interdoc Network Cold War Rationale (London: Palgrave Macmillan, 2012), 4.

xxxiii. Brogi. Confronting America, 111.

xxxiv. Michael E. Latham, The Right Kind of Revolution. Modernization, development and US Foreign Policy from the Cold War to the Present (Ithaca, London: Cornell University Press, 2011), 28 and 39.

xxxv. Brogi, Confronting America, 5. Jessica C.E. Gienow-Hecht, "Culture and the Cold War in Europe", The Cambridge History of the Cold War, Melvyn P. Leffler, Odd Arne Westad (eds), (Cambridge: Cambridge University Press, 2010) 398-419, doi: doi.org/10.1017/ CHOL9780521837194.020.

xxxvi. Cull, The Cold War, 55.

xxxvii. Ici New York was relayed daily by the French Radio, from 18.30 to 19.00 French time. Report by Radio Section. USIS. File no 811.20200 (D) 7-1946. Box 2383, RG59. 511.51 France, NARA, College Park, Maryland.

xxxviii. Telegraph from BRUCE to Secretary of State, July 2, 1951. Box 2390, RG59 511.5141, NARA, College Park, Maryland.

xxxix. Walter White was the executive director of the National Association for the Advancement of Colored People (NAACP).

xl. Report by Radio Section. File no 811.20200 (D) 7-1946. Box 2383, RG59. 511.51 France, NARA, College Park, Maryland.

xli. Mary Ann Glendon, A World made New. Eleanor Roosevelt and the Universal Declaration of Human Rights (New York: Random House, 2001).

xlii. Richard Gardner, "'First Lady' of the Voice of America." The New York Times (Feb 3 1952). ProQuest Historical Newspapers database.

xliii. Ibid.

xliv. Ibid.

xlv. Although the commentaries were delivered in French, here the English translations - issued as press releases of the US delegation to the UN - will be used. Press Release No. 1295, November 16, 1951. United States Delegation to the General Assembly of the United Nations, Eleanor 
Roosevelt Correspondence. UN Part I. Reel 26. 522-543, and Reel 27, 0649, Roosevelt Study Center Collection, Middelburg, the Netherlands.

xlvi. Ibid.

xlvii. For a discussion of listening publics at various times of day, see for example Donna Halper, Invisible Stars. A Social History of Women in American Broadcasting. (Armonk, NY; London, UK: M.E. Sharpe, 2001).

xlviii. The words in bold in the commentaries are my emphasis.

xlix. Translation L'Humanité December 17, 1951. Enclosure D to Despatch No 1667 of December 26, 1951 from AmEmbassy, Paris, France. Copy in Summary of USIS Radio Unit Activities Dec 1 1951, through May 31, 1952.

1. Summary of USIS Radio Unit Activities Dec 1 1951, through May 31, 1952.

li. Gardner, "First Lady of the Voice of America".

lii. Risso, "Radio Wars", 149.

liii. Nye, "Public Diplomacy", 336.

liv. The number of receivers in for example Yugoslavia was just 22 per 1000 inhabitants. Statistics on radio and television 1950-60. UNESCO statistical reports and studies (Paris:UNESCO, 1963).

lv. Summary of USIS Radio Unit Activities Dec 1 1951, through May 31, 1952. The use of capitals for VOICE OF AMERICA are in the original.

lvi. Container 1, P315 VOA Historical Files, NARA, College Park, Maryland.

lvii. Memorandum. January 5, 1952. Eleanor Roosevelt Correspondence. UN Part I. Reel 10. 584-589, Roosevelt Study Center Collection, Middelburg, the Netherlands.

lviii. Letter from Hulten to Barratt, 7 Jan 1952, Box 2390, RG 59, 511.5141, NARA, College Park, Maryland.

lix. Languages which she also spoke.

lx. John Robert Kelly, "US Public Diplomacy: A Cold War Success Story?" The Hague Journal of Diplomacy 2 (2007): 53-79.

lxi. Risso, "Radio Wars", 149.

lxii. Allida Black (2003). "Introduction", The Papers of Eleanor Roosevelt, 1945-1962. Part II: United Nations Correspondence and Publications (Bethesda, MD: UPA Collection, 2003).

lxiii. Ibid.

lxiv. My Day. 1 September 1951. The Eleanor Roosevelt Papers project. George Washington University. https://www.gwu.edu/ erpapers/myday/displaydoc.cfm?_y=1951\&_f=md002002.

lxv. My Day. 1 August 1950. The Eleanor Roosevelt Papers project. George Washington University. https://www.gwu.edu/ erpapers/myday/displaydoc.cfm?_y=1950\&_f=md001662.

\section{ABSTRACTS}

Eleanor Roosevelt wrote books, thousands of newspaper and magazine articles and was a regular broadcaster. Among the radio programs she hosted, and appeared on, were several for the Voice of America. While she was a US delegate to the United Nations in Paris in 1951 and 1952, Mrs. Roosevelt broadcast a series of weekly radio commentaries aimed at explaining to families in France and other French-speaking countries the workings of the UN and to urge Europeans to work together for peace. These weekly talks generated (as did all Mrs. Roosevelt's broadcasts) a 
great deal of letters from the public: usually either extremely favorable or vehemently opposed to the views she expressed. The former First Lady saw the role of the VOA as fundamental to "spread[ing] the understanding of the value of our way of life and of our type of government." This paper explores the connection between Eleanor Roosevelt and the official US radio propaganda in Europe in the early Fifties and the extent to which American cultural diplomacy benefitted from her presence on the airwaves.

\section{INDEX}

Keywords: Cold War, David Sarnoff, Edward W. Barratt, Eleanor Roosevelt, Fernande Auberjonois, France, James Webb, media, public diplomat, radio, Radio Free Europe, RDF, Richard Gardner, soft power, USIS, Voice of America

\section{AUTHOR}

\section{ANYA LUSCOMBE}

University College Roosevelt 